\title{
MILK IN HUMAN NUTRITION: COMPARISON OF FATTY ACID PROFILES
}

ARSIĆ ALEKSANDRA*, PREKAJSKI NIVESKA**, VUČIĆ VESNA*, TEPŠIĆ JASNA*, POPOVIĆ TAMARA*, VRVIĆ $M^{\star \star *}$ and GLIBETIĆ MARIJA*

$*$ Institute for Medical Research, Laboratory for Nutrition and metabolism, University of Belgrade,
Serbia; **Institute for Neonatology, University of Belgrade, Serbia;
***Faculty of Chemistry, Department of biochemistry, University of Belgrade, Serbia

(Received 5th May 2009)

Milk and milk products are very important in human nutrition. Fatty acids (FA), which are the major component of milk lipids, have different effects on human health. The aim of this study was to determine and compare fatty acid composition of human milk, infant formula and cow's milk most often consumed in Serbian population. Samples were analyzed by gas chromatography. Our results showed that saturated FA were predominant in all types of milk, particularly in cow's milk with more than $70 \%$. Monounsaturated oleic acid was significantly higher in human milk (36\%) than in infants formula (30\%) and cow's milk (26\%). Although polyunsaturated FA content of cow's milk was very low (3.6\%) compared with infant formula (15\%) and human milk (19\%), cow's milk had the most desirable $n 6 / n 3$ ratio, and content of $n-3$ precursor $\alpha$ linolenic acid. Low content of $n-3$ FA may be due to a relatively low consumption of marine foods in Serbian population. Long chain polyunsaturated fatty acids, which are important in infant development and maintenance of overall human health, were detected only in human milk. These results suggest that human milk is the most desirable food in infants' nutrition, but low content of $n-3$ FA indicates that supplementation of lactating women with $n-3$ FA is highly recommendable.

Key words: human milk, infant formula, essential fatty acid, arachidonic acid, docosahexaenoic acid

\section{INTRODUCTION}

Cow's milk and dairy products have a long tradition in human nutrition. The consumption of milk and milk products varies considerably among regions; from about $180 \mathrm{~kg}$ a year per capita in Island and Finland to less than $50 \mathrm{~kg}$ in Japan and China (Saxselin et al., 2003). Consumption of milk and milk products is about $70 \mathrm{~kg}$ a year per capita in Serbia and the most commonly used product is cow's milk (Stankovic, 2007). In addition, the most important foods for infants during the first year of life are human milk and infant formula. Milk is a source of lipids, 
proteins, amino acids, vitamins and minerals. As a metabolic source of energy milk lipids are necessary for normal body functions and are very important for growth and development. In average, milk contains about $4 \%$ of total lipids (Jensen et al., 1995). Triglycerides are the main lipid fraction which accounts for about $95 \%$ of total lipids. Other milk lipids are diacilglicerol (about $2 \%$ of the lipid fraction), phospholipids (about 1\%), cholesterol (less than $0.5 \%$ ) and free fatty acids accounting to less than $0.5 \%$ of total milk lipids (Jensen et al., 1995).

Fatty acids (FA) of different length and saturation are the major components of lipid molecules in milk. Medium-chain fatty acids (C:16) are synthesized in mammary glands, whereas long-chain saturated (SFA), monounsaturated (MUFA), as well as polyunsaturated FA (PUFA) come into mammary glands via the general circulation (Spear et al., 1992). More than half of milk FA are saturated FA, MUFA follow, while PUFA are present in the lowest concentrations. The composition of FA in diary products is particularly important because of their different effects on health. Some of SFA, such as lauric (12:0), myristic (14:0) and palmitic (16:0) acids raise blood cholesterol levels, and diets rich in saturated fats have been regarded as contributing to the development of heart disease, weight gain and obesity (Mensink et al., 2003). In contrast to this, capric (10:0), lauric (12:0) and stearic (18:0) acid may have neutral or even positive effects on health (Haug et al., 2007).

MUFA with the highest percentage in milk is oleic acid (18:1). This FA is considered to be beneficial for health, as diets with high amounts of MUFA decrease plasma cholesterol, LDL cholesterol and triglyceride concentration (Haug et al., 2007). Several studies indicate a cancer protective effect of oleic acid, though the data are not entirely convincing (Ip, 1997). The main PUFA in milk are linoleic (18:2n-6) and $\alpha$ linolenic (18:3n-3) acids which may be converted to arachidonic (AA, 20:4n-6) and eicosapentaenoic acids (EPA 20:5 n-3), and further to eicosanoids; metabolically very active molecules with local functions (Salem et al., 1996). Our previous data showed higher content of SFA, n-6 PUFA, higher n6/n-3 ratio and lower n-3 PUFA in serum and erythrocyte phospholipids in the Serbian population, which primarily reflects FA intake (Ristić et al., 2006).

Milk is a very good source of essential n-3 fatty acids. Children and adults usually consume cow's milk, while mother's milk in a main source of nutrients for newborns. When breastfeeding is not possible, standard or supplemented infant formulas are used. The content of SFA and MUFA is similar in cow's milk and in infant formula, but the total PUFA content differs significantly. Fat content and FA composition in human milk depend not only on their presence in mother's diet, but also on climatic, ethical, cultural and other circumstances. In contrast to cow's milk and infant formula, human milk contains small but significant amounts of long chain (LC) PUFA, particularly AA and DHA, which are necessary for optimal development of the brain (Crawford et al., 1981), the retina (Neuriger et al., 1984) and other infant tissues.

There is a lack of studies which compare FA profile in different types of milk used in human nutrition. The aim of this study was to determine and compare the FA composition of human milk, infant formula and cow's milk, which are most commonly consumed by the Serbian population. 
Acta Veterinaria (Beograd), Vol. 59. No. 5-6, 569-578, 2009.

\section{MATERIAL AND METHODS}

\section{Milk samples}

We examined cow's milk samples with 3.2 percentage of fat (Imlek, Belgrade, Serbia) which is most often used in the Serbian population. Samples were taken from more than one sales outlet type (supermarkets, local groceries), according to the EuroFIR recommendation. There were 3 primary samples. The examined infant formula (Impamil and Nan) is mostly used in Serbian maternity hospitals, and was prepared according to the manufacturer's protocol just before the extraction of FA.

The study also included 23 lactating mothers, which gave birth from June 2005 to September 2006 in Belgrade. None of them consumed fish more than twice per month, and they didn't take supplements. Breast-milk (5-10 mL) was manually collected into a sterile vessel on the $14^{\text {th }}$ day of lactation (mature milk), after the morning feeding of infants. FA were analyzed immediately after milk collection.

\section{FA extraction}

Milk fatty acids were extracted from $500 \mu \mathrm{L}$ of human milk, infant formula or cow's milk using the $4.5 \mathrm{~mL}$ chloroform-methanol mixture $(2: 1 \mathrm{v} / \mathrm{v})$. $1 \mathrm{~mL}$ of lipid extract was methylated and then analyzed for total fatty acid content in milk using gas chromatography (Shimadzu 2014, Kyoto, Japan ), fitted by Optima FFAP column. Fatty acid methyl esters were identified through the comparison of retention times with standard fatty acids (Sigma Aldrich Chemie, Taufkirchen, Germany).

\section{Statistical analysis}

All results are presented as means $\pm S D$. Profile comparisons were made using one-way ANOVA, followed by the Tuckey post hoc test. Differences were considered significant at $p$-values of $\leq 0.05$.

\section{RESULTS}

Although the content of fat in milk can vary, milk contains about $4 \%$ of total lipids. Fatty acids are lipid components and the most dominant are SFA, while MUFA and PUFA are present in lower concentrations. The aim of this study was to determine and compare FA composition of different milk types which are usually consumed by the Serbian population.

Our results show that the fat content in human milk varied from 3.5 to $4.5 \%$ and in infant formula it corresponded to label value which was 3.5\% (data not shown). The examined samples of cow's milk contained $3.2 \%$ fat.

SFA composition in milk samples

Our study showed that the percentage of total SFA was significantly higher in cow's milk $(70.15 \pm 2.43)$ than in infants formula $(55.17 \pm 2.02, p<0.001)$ and human milk $(44.3 \pm 4.86, p<0.001)$. In addition, the content of single SFA 
significantly differed among examined milk types. Results are presented in Table 1. The most prevailing FA in all three types of milk was saturated palmitic acid

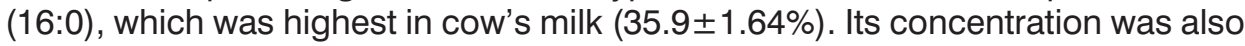
significantly higher in infants formula $(28.57 \pm 0.52 \%)$ than in human milk $(22.24 \pm 2.32 \%)$. The percentages of the other SFA such as capric (10:0), myristic (14:0) and stearic acid (18:0) were also highest in cow's milk. Only the content of lauric acid (12:0), from all SFA, was higher in human milk than in cow's milk (Table 1).

Table 1. Percentages of saturated fatty acids (SFA) in cow's milk, baby formula and human milk

\begin{tabular}{|c|c|c|c|}
\hline $\begin{array}{c}\text { Fatty acid } \\
\%\end{array}$ & Cow's milk & Baby formula & Human milk \\
\hline $10: 0$ & $2.33 \pm 0.61$ ***\#\#\# & $0.32 \pm 0.02 \& \&$ & $1.04 \pm 0.34$ \\
\hline $12: 0$ & $3.34 \pm 0.64$ * & $6.66 \pm 0.18$ & $6.48 \pm 1.96$ \\
\hline $14: 0$ & $12.60 \pm 1.07 * \star *$ & $9.50 \pm 0.50$ & $7.44 \pm 2.19$ \\
\hline $15: 0$ & $1.28 \pm 0.04$ & $\mathrm{Nd}$ & $0.35 \pm 0.29$ \\
\hline $16: 0$ & $35.90 \pm 1.64 * * * \# \#$ & $28.57 \pm 0.52 \& \& \&$ & $22.24 \pm 2.32$ \\
\hline $17: 0$ & $0.81 \pm 1.95$ & $\mathrm{Nd}$ & $0.40 \pm 0.13$ \\
\hline $18: 0$ & $11.63 \pm 0.98^{* \star *}$ & $10.41 \pm 0.52 \& \& \&$ & $6.45 \pm 0.98$ \\
\hline Total SFA & $70.15 \pm 2.43^{* \star \star \# \# \# ~}$ & $55.17 \pm 2.02 \& \&$ & $44.30 \pm 4.86$ \\
\hline
\end{tabular}

*indicates significant difference between cow's and human milk; \# indicates significant difference between cow's and baby formula; $\&$ shows significant differences between baby formula and human milk; *, \# , or \& means $p<0.05, * * ; \#$ or \&\& mean $p<0.01 ; * \star *$, \#\#\# or \&\&\& mean $p<0.001$

\section{MUFA composition in milk samples}

We found that total MUFA, as well as oleic acid $(18: 1, \mathrm{n}-9)$ content were significantly lower in cow's milk $(26.17 \pm 2.04,23.97 \pm 0.95$, respectively) when compared to infant formula $(30.06 \pm 1.0,30.4 \pm 0.7)$ and particularly to human milk $(36.56 \pm 3.24,32.78 \pm 3.27$ ) (Table 2).

\section{PUFA composition in milk samples}

Total PUFA in cow's milk was very low (only $3.6 \pm 0.57 \%$ ), while in infant formula and in human milk PUFA participated with significant percentages $(15.0 \pm 2.0$ and 19.1 \pm 3.91 , respectively). As it can be seen in Table 3, the linoleic acid (18:2) percentages in human milk and baby formula were similar $(16.29 \pm 3.63,14.03 \pm 1.00$ respectively), while samples of cow's milk contained only $1.02 \pm 0.1 \%$ of this FA. However, the content of $\alpha$-linolenic acid and total $n-3$ were slightly lower in human milk and infant formula when compared to cow's milk (Table 3). 
Acta Veterinaria (Beograd), Vol. 59. No. 5-6, 569-578, 2009.

Arsić Aleksandra et al.: Milk in human nutrition:

comparison of fatty acid profiles

Table 2. The percentages of monounsaturated fatty acids (MUFA) in cow's milk, baby formula and human milk

\begin{tabular}{|c|c|c|c|}
\hline $\begin{array}{c}\text { Fatty acid } \\
\%\end{array}$ & Cow's milk & Baby formula & Human milk \\
\hline \hline $14: 1$ & $\mathrm{Nd}$ & $\mathrm{Nd}$ & $0.24 \pm 0.26$ \\
\hline $16: 1 \mathrm{n}-9$ & $\mathrm{Nd}$ & $\mathrm{Nd}$ & $2.50 \pm 0.92$ \\
\hline $18: 1 \mathrm{n}-9$ & $23.97 \pm 0.95 * \star \star \#$ & $30.40 \pm 0.7$ & $32.78 \pm 3.27$ \\
\hline $20: 1 \mathrm{n}-9$ & $\mathrm{Nd}$ & $\mathrm{Nd}$ & $1.04 \pm 0.80$ \\
\hline $24: 1 \mathrm{n}-9$ & $\mathrm{Nd}$ & $\mathrm{Nd}$ & $0.10 \pm 0.09$ \\
\hline \hline Total MUFA & $26.17 \pm 2.04^{\star \star *}$ & $30.06 \pm 1.0 \& \&$ & $36.56 \pm 3.24$ \\
\hline
\end{tabular}

All abbreviations as in Table 1.

Table 3. The percentages of polyunsaturated fatty acids (PUFA) in cow's milk, baby formula and human milk

\begin{tabular}{|c|c|c|c|}
\hline $\begin{array}{c}\text { Fatty acid } \\
\%\end{array}$ & Cow's milk & Baby formula & Human milk \\
\hline \hline $18: 2 \mathrm{n}-6$ & $1.02 \pm 0.01^{\star \star * \# \# \#}$ & $14.03 \pm 1.00$ & $16.29 \pm 3.63$ \\
\hline $18: 3 \mathrm{n}-6$ & $\mathrm{Nd}$ & $\mathrm{Nd}$ & $0.12 \pm 0.10$ \\
\hline $18: 3 \mathrm{n}-3$ & $2.92 \pm 0.12^{\star \star \star \# \# \#}$ & $0.80 \pm 0.20$ & $0.49 \pm 0.23$ \\
\hline $20: 2 \mathrm{n}-6$ & $\mathrm{Nd}$ & $\mathrm{Nd}$ & $0.56 \pm 0.13$ \\
\hline $20: 3 \mathrm{n}-6$ & $\mathrm{Nd}$ & $\mathrm{Nd}$ & $0.57 \pm 0.18$ \\
\hline $20: 4 \mathrm{n}-6$ & $\mathrm{Nd}$ & $\mathrm{Nd}$ & $0.51 \pm 0.11$ \\
\hline $20: 5 \mathrm{n}-6$ & $\mathrm{Nd}$ & $\mathrm{Nd}$ & $0.10 \pm 0.05$ \\
\hline $22: 4 \mathrm{n}-6$ & $\mathrm{Nd}$ & $\mathrm{Nd}$ & $0.19 \pm 0.13$ \\
\hline $22: 5 \mathrm{n}-3$ & $\mathrm{Nd}$ & $\mathrm{Nd}$ & $0.09 \pm 0.04$ \\
\hline $22: 6 \mathrm{n}-3$ & $\mathrm{Nd}$ & $\mathrm{Nd}$ & $0.19 \pm 0.07$ \\
\hline \hline Total PUFA & $3.60 \pm 0.57^{\star \star \star \# \#}$ & $15.00 \pm 2.00$ & $19.10 \pm 3.91$ \\
\hline $\mathrm{n}-6$ & $1.02 \pm 0.10^{\star \star \star \# \# \#}$ & $14.06 \pm 1.00$ & $18.24 \pm 3.80$ \\
\hline $\mathrm{n}-3$ & $2.92 \pm 0.12^{\star \star \star \# \# \#}$ & $0.80 \pm 0.10$ & $0.86 \pm 0.29$ \\
\hline $\mathrm{n}-6 / \mathrm{n}-3$ & $0.35 \pm 0.02^{\star \star \star \# \#}$ & $17.42 \pm 0.80$ & $22.65 \pm 6.16$ \\
\hline
\end{tabular}

All abbreviations as in Table 1.

The percentage of $n-6$, as well as the $n-6 / n-3$ ratio, were significantly higher in human milk (18.24 \pm 3.80 and $22.65 \pm 6.16$, respectively) when compared to infant formula (14.06 \pm 1.00 and 17.42 \pm 0.80 , respectively). Cow's milk, however, contained only $1.02 \pm 0.10 \%$ of $n-6$. Such a low content of $n-6$ PUFA also caused a very low $n-6 / n-3$ ratio in cow's milk $(0.35 \pm 0.02)$. Long chain PUFA were detected exclusively in human milk, as expected. 


\section{DISCUSSION}

Regarding the different influence of single FA on human health, the main goal of our investigation was to determine to what extent FA profiles differ in three types of milk (human milk, infant formula and cow's milk) which are the most commonly consumed milks in the Serbian population.

Our results showed significant differences in FA content among the three types of milk. In all analyzed samples, saturated FA were the most prevalent, particularly in cow's milk where SFA participated with about $70 \%$. However, USDA National Nutrient Database for Standard Reference data showed that bovine milk contained about $58 \%$ of SFA. Percentages of single saturated fatty acids differed as well. Thus, in our study, the percentage of lauric acid (12:0), was higher in human milk when compared to cow's milk, which may have beneficial effects on the health of infants. This fatty acid has antiviral and antibacterial functions (Sun et al., 2002), and might act as an anti caries and anti plaque agent (Schuster et al.,1980). In contrast to this, saturated FA, such as myristic (14:0) and palmitic $(16: 0)$ acids have low-density lipoprotein (LDL) and total cholesterol-increasing properties, so that high intake of these FA contributes to the development of cardiovascular diseases (Haug et al., 2007). In our study the percentage of myristic and palmitic acids was highest in cow's milk. Palmitic acid was also significantly higher in infant formula than in breast milk. Interestingly, although it belongs to the SFA group, stearic acid (18:0) does not seem to increase serum cholesterol concentration, and is not atherogenic (Grundy, 1994). Our study also showed the highest concentration of stearic acid in cow's milk. A study by Jensen et al. showed that percentage of myristic and palmitic acids was higher in bovine milk compared to human milk, whereas the percentage of stearic acid was similar in bovine and human milk (Jensen et al.,1990). These results indicate that, although the consumption of $0.5 \mathrm{~L}$ of milk per day supplies a significant amount of required nutrients (Haug et al., 2007). Special attention should be payed to the high content of SFA in cow's milk, as in our study showed, when deciding on daily quantities of milk consumption.

The most prevalent unsaturated FA in all types of milk was oleic acid. Its concentration in whole cow's milk is about $8 \mathrm{~g} / \mathrm{L}$ (USDA National Nutrient Database for Standard Reference) so milk and milk products substantially contribute to the dietary intake of oleic acid in many countries (Haug et al., 2007). Comparing oleic acid content in infant formula, cow's and human milk, we found the highest concentration of this FA in human milk. The well-known beneficial effects of oleic acid on human health (Haug et al., 2007) make its content in milk very important. The percentage of undesirable SFA in cow's milk can be replaced with desirable MUFA and PUFA by inclusion of feed components in cow's nutrition such as rapeseed, soybean or linseed oils (Collomb et al., 2004), that could have significant health benefits for humans (Visioli et al., 2000). The study by Komprda et al., (2005) showed that feed mixture containing rapeseed, rapeseed oil and rapeseed cakes significantly decreased the content of palmitic acid and, at the same time, increased the content of stearic, oleic, linoleic and $\alpha$ linoleic acid in the milk of these cows. 
Arsić Aleksandra et al.: Milk in human nutrition:

comparison of fatty acid profiles

The precursors of LC PUFA n-6 and n-3 families are linoleic (18:2, n-6) (LA) and $\alpha$ linolenic $(18: 3, n-3)$ acids, respectively. These FA are essential for mammals and therefore must be present in the human diet (Uauy et al., 2000). We found that the percentage of $n-6$ precursor LA was lowest in cow's milk (only $1.02 \pm 0.01 \%$ compared with $16.29 \pm 3.63 \%$ in human milk), while the percentage of $\alpha$ LA ( $n-3$ precursor) was lowest in human milk. Consequently, the percentage of total PUFA and n-6 PUFA were highest in human milk, but also significantly higher in infant formula than in cow's milk. These findings are very important, considering that $n-6$ PUFA are necessary for growth and development, for liver and kidney function, heart contractility, and skin permeability in infants (Carlson et al., 1992). In adults, decreased level of total PUFA, mainly of $n-6$ family, was observed in patients with insulin resistance (Borkman et al., 1993). On the contrary, total n-3 FA content was higher in cow's milk compared to human milk and infant formula. A recent study suggested that high supplementation of milk with n-3 FA in Iceland might explain the lower prevalence of type-2 diabetes and coronary heart disease mortality in Iceland compared to other European countries (Thorsdottir et al., 2004). Postnatal deficiency in n-3 PUFA in infants has been associated with neural and retinal complications (San Giovanni et al., 2000), and it may be associated with metabolic syndrome in adults (Kabagambe et al., 2008).

Long chain polyunsaturated fatty acids $(\mathrm{C} \geq 20)$ play an important role in infant development and the maintenance of overall human health, either as a component of membrane phospholipids, or as precursors to various eicosanoids (Jump, 2002). These FA were not detected in cow's milk and milk formula, but only in human milk. AA is the precursor of prostaglandins and leukotrienes and is essential for neonatal growth (Carlson et al., 1992), whereas DHA is necessary for visual and cognitive development in infants and children. Recent epidemiologic and preclinical studies also suggest that DHA may protect against Alzheimer disease and other types of dementia (Arterburn et al., 2006). Cardiovascular benefits have been attributed to long-chain $n-3$ fatty acids. All LC $n-3$ fatty acids may protect against advanced age-related macular degeneration, suggesting a continued role of these fats in brain and eye health in both adults and the elderly (Arterburn et al., 2006). Concentrations of DHA and AA in breast milk were lower in our study than in the studies conducted in Japan, Dominican Republic, Philippines and Congo (DHA 0.6-1.4\%), but were in accordance with reports from Pakistan, Canada, the Netherlands and France (0.06-0.14\%) (Brenna et al., 2007). The latter are the countries which are usually associated with low marine food consumption. Nutritional habits in the Serbian population, with its rare consumption of marine foods, could also explain a lower concentration of this FA in human milk. Thus, extreme values were consistent with studies suggesting that marine food-consuming populations have greater breast milk DHA concentration (Olafsdottir et al., 2006; Ogunleye et al., 1991), as well as lower rates of coronary heart disease and some cancers (Bartsch et al., 1999). Furthermore, eicosanoids derived from LA via AA, may enhance blood platelet aggregation and thereby increase the coronary risk, in contrast to eicosanoid products from $\alpha \mathrm{LA}$ (Haug et al., 1992). EPA has the ability to partially block the conversion of $n-6$ acids to 
harmful eicosanoids, thereby reducing the cardiovascular risk and inhibiting tumor genesis (Bagga et al., 2003).

The balance between total n- 6 and n-3 FA in the diet is important because of their competitive nature. For optimal infant nutrition, the ratio of $n-6 / n-3$ must not be higher than 10 (Gerster, 1998). However, in the present study this ratio was higher than recommended for both formula milk (17.42 \pm 0.80$)$ and particularly for human milk $(22.65 \pm 6.16)$. In countries where mothers consumed high amounts of fish rich in n-3 PUFA, such as the Netherlands (Boersma et al., 1990), or Malaysia (Kneebone et al., 1985), these $n-6 / n-3$ ratios were significantly lower than in our country ( 8.5 and 6.5 respectively). However, this difference in $n-6 / n-3$ ratio between Serbian and these women, occured not only due to a relatively low consumption of marine foods, but also due to a relatively high consumption of plant oils rich in n-6 PUFA. On the contrary, $n-6 / n-3$ ratio in cow's milk in our study was only $0.35 \pm 0.02$, which was even significantly lower than the data from Nordic countries: Iceland (2.1) and Norway (4.7) (Haug et al., 2007).

This study compared three types of milk samples and indicated that human milk is the best food for infants in terms of fatty acids. However, due to deficiency of $\mathrm{n}-3$ in Serbian women, supplementation with n-3 FA during lactation and supplementation of baby formulas is highly recommended. Cow's milk is recommendable for children and adults because of its high percentage of n-3 FA, in particular $\alpha \mathrm{LA}$ and its good $\mathrm{n} 6 / \mathrm{n} 3$ ratio, but its high content of SFA should be replaced by MUFA and PUFA during milk production.

ACKNOWLEDGEMENT:

This study was supported by a grant from the Serbian Ministry of Science, Project No 145071.

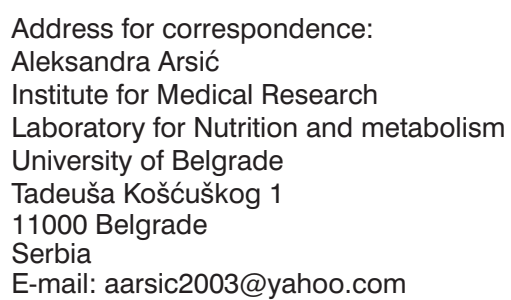

\section{REFERENCES}

1. Arterburn LM, Hall EB, Oken H, 2006, Distribution, interconversion, and dose response of $\mathrm{n}-3$ fatty acids in humans, Am $J$ Clin Nutr, 83, 6, 1467S-76S.

2. Bagga D, Wang L, Farias-Eisner R, Glaspy JA, Reddy ST, 2003, Differential effects of prostaglandin derived from omega- 6 and omega-3 polyunsaturated fatty acids on COX-2 expression and IL-6 secretion, Proc Natl Acad Sci USA, 100, 1751-6.

3. Bartsch H, Nair J, Owen RW, 1999, Dietary polyunsaturated fatty acids and cancers of the breast and colorectum: emerging evidence for their role as risk modifiers, Carcinogenesis, 20, 220918.

4. Boersma ER, Offringa PJ, Muskiet FAJ, Chase WM, Simmons IJ, 1991, Vitamin E, lipid fractions and fatty acid composition of colostrum, transitional milk and mature milk: an international comparative study, Am J Clin Nutr, 53, 1197-204. 
5. Borkman M, Storlien LH, Pan DA, Jenkins AB, Chisholm DJ et al., 1993, The relation between insulin sensitivity and fatty-acid composition of skeletal-muscle phospholipids, $N$ Engl J Med, 328, 238-44.

6. Brenna TJ, Varamini B, Jensen RG, Diersen-Schade DA, Boettcher JA et al., 2007, Docosahexaenoic and arachidonic acids concentrations in human breast milk worldwide, $A m \mathrm{~J}$ Clin Nutr, 85, 1457-64.

7. Carlson SE, Werkman SH, Peeples JM, Cooke RJ, Wilson WM, 1992, Plasma phospholipids arachidonic acid and growth and development of preterm infants, In: B Koletzko, A Okken,J Rey, B. Salle and JP Van Biervliet, editors, Symposium; Recent Advances in Infants Feeding, Stuttgart: Georg Thieme Verlag, 22-7.

8. Crawford MA, Hassam AG, Stevens PA, 1981, Essential fatty acid requirements in pregnancy and lactation with special reference to brain development, Prog Lipid Res, 20, 31-40.

9. Collomb M, Sollberger H, Butikofer U, Sieber R, Stoll W et al., 2004, Impact of a basal diet of hay and fodder beet supplemented with rapeseed, linseed and sunflower seed on the fatty acids composition of milk fat, Int Dairy J, 14, 549-59.

10. Gerster $H, 1998$, Can adults adequately convert alfa-linolenic acid to eicosapentaenoic acid and docosahexaenioc acid, Int J Vitam Nutr Res, 68, 159-73.

11. Grundy SM, 1994, Influence of stearic acid on cholesterol metabolism relative to other long-chain fatty acids, Am J Clin Nutr, 60, 986S-90S.

12. Haug A, Hallaq $H$, Leaf A, 1992, Potential antiatherogenic effect of omega-3 fatty acids In: Neri Serneri SS, Gensini GF, Abbate R, Prisco D, editors, Thrombosis, an update, Scientific press, Florence, 361-72.

13. Haug A, Hostmark AT, Harstad OM, 2007, Bovine milk of human nutrition - a review, Lipids in Health and Disease, 6, 25-41.

14. Ip C, 1997, Review of the effect of trans fatty acids, oleic acids, $\mathrm{n}-3$ polyunsaturated fatty acids, and conjugated linoleic acid on mammary carcinogenesis in animals, Am J Clin Nutr, 66,1523S-9S.

15. Jensen RG, Ferris A, Lammi-Keffe CJ, Henderson RA, 1990, Lipids of Bovine and Human Milks: A Comparison, J Dairy Sci, 73, 223-40.

16. Jensen RG, Newburg DS, 1995, Bovine milk lipids, In Jensen RG, editor, Handbook of milk composition, Academic Press, USA, 543-75.

17. Jump D, 2002, The biochemistry of n-3 polyunsaturated fatty acids, J Biol Chem, 277, 8755-8.

18. Kabagambe EK, Tsai MY, Hopkins PN, Ordovas JM, Peacock JM, et al., 2008, Erythrocyte Fatty Acid Composition and the Metabolic Syndrome: A National Heart, Lung, and Blood Institute GOLDN Study, Clinical Chemistry, 54, 154-62.

19. Kneebone GM, Kneebone R, Gibson RA, 1985, Fatty acid composition of breast milk from three racial groups from Penang, Malaysia, Am J Clin Nutr, 41, 765-9.

20. Komprda T, Dvorak R, Fialova M, Sustova K, Pechova A, 2005, Fatty acid content in milk of dairy cows on a diet with high fat conted derived from rapeseed, Czech J Anim Sci, 50, 311-9.

21. Mensink RP, Zock PL, Kester AD, Katan MB, 2003, Effects of dietary fatty acids and carbohydrates on the ratio of serum total to HDL cholesterol and on serum lipids and apolipoproteins: a metaanalysis of 60 controled trials, Am J Clin Nutr, 77, 1146-55.

22. Neuriger M, Connor WE, Van Petten C, Borstad C, 1984, Dietary omega-3 fatty acid deficiency and visual loss in infant rhesus monkeys, J Clin Invest, 73, 272-6.

23. Olafsdottir AS, Thorsdottir I, Wagner KH, Elmadfa I, 2006, Polyunsaturated fatty acids in the diet and breast milk of lactating Icelandic women with traditional fish and cod liver oil consumption, Ann Nutr Metab, 50, 270-6.

24. Ogunleye A, Fakoya AT, Niizeki S, 1991, Fatty acids composition of breast milk from Nigerian and Japanese women, J Nutr Sci Vitaminol (Tokyo), 37, 435-42.

25. Ristić V, Tepšić V, Ristić-Medić D, Peruničić G, Rašić Z, et al, 2006, Plasma and erythrocyte phospholipid fatty acid composition in Serbian hemodialyzed patients, Ren Fail, 28, 211-6.

26. Salem N, Wegher B, Mena P, Uauy R, 1996, Arachidonic and docosahexaenoic acids are biosynthesized from their 18-carbon precursors in human infants, Proc Natl Acad Sci USA, 93, 49-54. 
27. San Giovanni JP, Berkey CS, Dwyer JT, Colditz GA, 2000, Dietary essential fatty acids, long-chain polyunsaturated fatty acids, and visual resolution acuity in healthy fullterm infants: a systematic review, Early Hum Dev, 57, 165-88.

28. Saxselin M, Korpela R, Mayra-Makinen A, 2003, Introduction: Classifying functional diary products, In Mattila-Sandholm T, Saarela M, editors, Functional dairy products, Woodhead Publishing Limited, UK, 1-16.

29. Schuster GS, Dirksen TR, Ciarlone AE, Burnett GW, Reynolds MT, et al 1980, Anticaries and antiplaque potential of free-fatty acids in vitro and in vivo, Pharmacol Ther Dent, 5, 25-33.

30. Stankovic V, 2008, http://www.agropres.org.yu

31. Spear ML, HamoshM, Bitman J, Spear M, Wood LD, 1992, Milk and blood fatty acid composition during two lactations in the same woman, Am J Clin Nutr, 56, 65-70.

32. Sun CQ, O'Conor CJ, Roberton $A M, 2002$, The antimicrobial properties of milk fat after partial hydrolysis by calf pregastric lipase, Chem Biol Interact, 140, 185-98.

33. Thorsdottir I, Hill J, Ramel A, 2004, Omega-3 fatty acid supply from milk associates with lower type 2 diabetes in men and coronary heart disease in women, Prev Med, 39, 630-4.

34. Uauy $R$, Valenzuela A, 2000, Marine oils: the health benefits of $n-3$ fatty acids, Nutrition 16, 680-4.

35. http://www.nal.usdagov/fnic/foodcomp/Data. USDA National Nutrient Database for Standard Reference, 2007,

36. Visioli F, Rise P, Plasmati E, Pazzucconi F, Sirtori CR et al., 2000, Very low intake of n-3 fatty acids incorporated into bovine milk reduce plasma triacylglycerol and increase HDL-cholesterol concentration in healty subjects, Pharmacol Res, 41, 571-6.

\title{
MLEKO U LJUDSKOJ ISHRANI: POREĐENJE PROFILA MASNIH KISELINA
}

\author{
ARSIĆ ALEKSANDRA, PREKAJSKI NIVESKA, VUČIĆ VESNA, TEPŠIĆ JASNA, \\ POPOVIĆ TAMARA, VRVIĆ M I GLIBETIĆ MARIJA.
}

\section{SADRŽAJ}

Mleko i mlečni proizvodi su od velikog značaja za ljudsku ishranu. Masne kiseline (MK), koje su glavna komponenta lipida mleka, imaju različite efekte na zdravlje. Iz tog razloga, cilj ove studije je bio da se odredi i uporedi sastav masnih kiselina u humanom mleku, formuli za ishranu novorođenčadi i kravljem mleku, koji se uobičajeno konzumiraju u Srbiji. Uzorci su analizirani gasnom hromatografijom. Naši rezultati su ukazali da su zasićene MK najzastupljenije u svim tipovima mleka, posebno u kravljem, gde čine više od 70\% ukupnih MK. Mononezasićena oleinska kiselina bila je značajno zastupljenija u humanom mleku (36\%) nego u formuli (30\%) i kravljem mleku (26\%). Mada su polinezasićene MKu kravljem mleku zastupljene u vrlo niskom procentu (3.6\%) u poređenju sa formulom (15\%) i humanim mlekom (19\%), kravlje mleko je imalo najpoželjniji odnos n6/n3 MK, i sadrzaj n-3 prekursora $\alpha$-linoleinske kiseline. Nizak sardžaj n-3 MK u humanom mleku je posledica slabe zastupljenosti morskih plodova u ishrani u Srbiji. Dugolančane polinezasićene MK, koje su od izuzetnog značaja za razvoj novorođenčadi i očuvanje zdravlja uopšte, detektovane su samo u humanom mleku. Ovi rezultati ukazuju da je humano mleko najpoželjnija hrana za novorođenčad, ali nizak sadrzaj n-3 MK ukazuje da je suplementacija dojilja preparatima n-3 MK veoma preporučljiva. 